\title{
Students' Self-Regulated Learning in English Classroom
}

\author{
Melda Yeni ${ }^{1,}$ Maizarah $^{2}$, M. Ridhwan ${ }^{3}$ \\ ${ }^{1}$ Universitas Islam Indragiri, Riau, Indonesia \\ email: meldayeni@outlook.com \\ ${ }^{2}$ Universitas Islam Indragiri, Riau, Indonesia \\ email: maizarah_nurzainal@yahoo.com \\ ${ }^{3}$ STAI Auliaurrasyidin Tembilahan, Riau, Indonesia \\ email: ridhwan@stai-tbh.ac.id
}

\begin{abstract}
:
This paper aims to explore English students' self-regulated learning and its factors. A quantitative survey method using total sampling techniques was administered toward 118 eleventh-grade students of SMAN 1 Tembilahan Hulu-Riau. The data were collected directly using a Likert scale questionnaire derived from a careful examination of the works of literature. The data then analyzed using a descriptive mean formula and further interpreted qualitatively to answer the formulated questions. The results showed that students' self-regulated learning in the English classroom is at the "enough" level. This result was influenced by four factors, namely: The support of environment, technology, confidence, and a desire to learn independently.
\end{abstract}

\section{Keywords: English Classroom, Factors, Self-Regulated Learning}

\section{INTRODUCTION}

Textually, the term of Self-Regulated Learning (SRL) has been in our education law proposed to develop students' creativity (National Ministry of Education Indonesia, 2003, Chapter II, article 3). However, on the situation, SRL by this law means the students need to work hard to acquire their skills to be self-regulated learners.

Being self-regulated learners does not mean learning alone without any help from others. Schraw et al., (2006) point out that environmental factors are very influential such as quality of instruction, teacher feedback, access to information, and help from peers and parents. Every level of students needs to be SRL to succeed in their learning. Secondary school level, for instance, students who are SRL getting more directions to escape from any barriers they face during the teaching and learning process. Yet, there was limited empirical research found about this issue, especially in Tembilahan Riau Indonesia. Researchers, throughout this research examined how students' self-regulated learning in the English classroom, and the factors influence them to be self-regulated learners.

Literature shows that SRL is very crucial in the process of teaching and learning, it clearly defined that study about SLR has been discussed for two decades (Mustofa et al., 2019), and it is the most popular research topic in education and psychology (Xiao et al., 2019). Another study by Zumbrunn et al. (2011) also explained that as a mechanism SRL helps 
students controlling their feelings, actions, and emotions in order to handle their learning experiences effectively. For this reason, it seems reasonable that learners need this process; they can optimize their academic performance by being purposive and goal-oriented learners (Xiao et al., 2019 , p.1) as well as having phases of learning; before, during, and after (Peel, 2020, p.261).

Zimmerman (2013), the first wellknown author in SRL illustrates that there are three phases of SRL involving forethought, performance, and selfreflection (as cited in Peel, 2020; Panadero, 2017). Those three phases can lead to learner's performance in what to do before they learn, i.e., goal setting or preparing some strategies, guiding them to choose better approaches during learning, and conducting self-evaluation after learning.

Similarly, Cheng, (2011) describes that in the process of self-regulated learning, learners should be able to set their goal, making a learning plan, choosing appropriate learning strategies, monitoring while they learn, evaluating what they get in learning, and controlling obstacles. As such, SRL students never give up on any condition that can make them down in the process of learning, they will keep trying to achieve their goal. For example, when they face a new task that requires knowledge and skills, but they have not learned yet, the self-regulated learner will find strategies for how to finish the task and solve the problem (Ozan et al., 2012). Thus, self-regulated learning involves both abilities to accomplish learning responses by oneself and the capability to change learning responses to the new one or shifting negative conditions in learning to a positive one. Therefore, at this level, learners not only becoming self-regulated in a metacognitive sense but also self-motivated too (Zimmerman, 1990). In their research, Xiao et al., (2019) also found that highly self-regulative learners are academically more successful than those students with lower self-regulation, or those who lack regulation in their learning.

In another theory, the process of selfregulated learning according to Zumbrunn et al., (2011) includes first: goal setting, which can be as straightforward as receiving a good grade on an exam, or as thorough as having a broad understanding of a subject, to achieve long-term aspirations, short-term achievable targets are also used. Second: planning which has three phases: setting a target for a learning mission, designing strategies to achieve the goal, and deciding how much time and money are required to achieve the goal. Third: self-motivation that happens when a learner uses one or more methods individually to keep himself on track towards a learning target. Fourth: Attention Control which is a cognitive mechanism that needs substantial self-monitoring. Fifth: flexible learning defines as efficient learners who can incorporate multiple learning strategies through tasks and adapt those strategies to promote their progress towards their desired objectives, as necessary. Sixth: Self-Monitoring by tracking their progress towards learning objectives, and able to monitor themselves. Seventh: Help-Seeking, Self-regulated students do not attempt to carry out every assignment on their own, but also seek assistance from others when necessary. The last is self-evaluation who can measure their learning individually. 
Although being self-regulated learning has some advantages, in fact, being self-regulated learners is complicated. They need teachers and others to help them being self-regulated. As argued by Chalachew \& Lakshmi (2013), learners themselves are factors. In this case, Chalachew \& Lakshmi (2013) further elaborated the key factors by learners against their overall academic achievement, those are:

a. Method of classifying and locating undergraduate students in various departments and schools.

b. The absence of a place to research and a conducive climate.

c. Inappropriate usage and continuous evaluation application.

d. The shortage of critical and technical tools at universities.

e. Lack of confidence from students

f. The lack of preparation by students for their academic assignments.

g. The lack of use by the teachers of different teaching methods.

Consequently, teachers have a crucial role in realizing learners' selfregulated learning, it is the job of the teacher to guide students to be selfregulated learners by comprehensively implementing some steps in her or his classrooms. Reis and Green (2002) in Harding's article (2018) reveals that teachers can use the following approaches to help students improving SRL skills:

a. Direct the self-belief, goal setting, and aspirations of students by
1) Developing background knowledge

2) Discussing specific SRL strategies

3) Modelling or instructing in SRL strategies

b. Provide access to dialogue that is reflective (including strategies for self-talk)

c. Provide remedial input

d. Help students create strategies to create ties between abstract concepts

e. Help students connect new experiences with prior learning automatically

f. Require students to reflect, assess and document effective strategies and procedures to minimize ineffective strategies.

Taken together, the earlier related literature of its findings of SRL and factors, however, retreat some questions and disparities that may affect discrepancy or even similarity while going under research on researchers' range of study. It is just like high school levels are very different than those who are on a higher degree. Investigating high school students' selfregulated learning is undeniably important, especially to understand learners' situations in the classroom.

\section{METHOD}

A quantitative survey method was used in this study to determine students' SRL and its influence factors. The data were collected directly using a Likert scale questionnaire derived from a careful examination of the literature towards 118 eleventh-grade students of SMAN 1 Tembilahan Hulu Riau. There were two sessions administered in this total sampling 
technique, the first twelve items to answer students' SRL, and another six to answer its factors. The data then analyzed using a descriptive mean formula, and further interpreted qualitatively to answer the formulated questions.

In short, the survey questionnaires scaled from one to five intervals from the highest to the lowest score. They were "strongly agree/always (5), agree/often (4), neutral/sometimes (3), disagree/seldom (2), and strongly disagree/never (1)".

\section{FINDINGS AND DISCUSSIONS}

Based on five categorical interval data in the questionnaire, it revealed that learners' self-regulated learning was simply categorized into "sometimes or enough" level. Proving by the data from the total score on each item is only 394.5. This score ranged between 308 - 402 in the interval score table illustrated in table 1 :

Table 1. Self-regulated and Factors classification

\begin{tabular}{cc}
\hline Interval & $\begin{array}{c}\text { Self-regulated and Factor } \\
\text { classification }\end{array}$ \\
\hline $496-590$ & Always/Strongly Agree \\
$401-495$ & Often/Agree \\
$308-402$ & Sometimes/Neutral \\
$213-307$ & Seldom/ Disagree \\
$118-212$ & Never/Strongly disagree \\
\hline
\end{tabular}

(Adapted from Widoyoko, 2014).

Congruent with the above findings, then, the result of questionnaire factors exposed four themes that influence students' self-regulated learning. Those factors substantiate the earlier findings that only four factors from all seven available factors may interfere with learners' selfregulated learning. The factors are as follows:
a. The support of the environment
b. The support of technology
c. Having high confidence to learn independently, and
d. Having a desire to learn independently

In agreement with the above findings, all the four findings about the factors influencing learners' self-regulated learning were selected and spotted by respondents within an "agree" interval. Therefore, from 6 statements in the questionnaire, the respondents agree that only four factors that influenced their self-regulated learning.

The data, as such, can finally answer the two objectives of this research. The first question about how is students' selfregulated learning at grade XI SMAN 1 Tembilahan Hulu? As well as answering what are the factors influencing their selfregulated learning?

In consideration of interpreting the findings of the first questions, the data analysis revealed that students' selfregulated learning was only categorized into "enough" it means that most of the respondents have been able to manage themselves during the teaching and learning process. They know what to do to obtain better achievements in learning. Nevertheless, they still need to develop their skills on how to be a self-regulated learner, they also need to expanse their selfregulated learning level becoming better and better.

Likewise, the data also revealed that environment and technology became the first dominant factor influencing the 
"enough" result. Then confidence and having a desire to learn independently become the second. Consequently, those findings proved that being self-regulated learners need support internally or externally. In other words, self-regulated students would be automatically having self-confidence and would be a desire to learn by themselves, although they may need encouragement and motivation from their environments.

In accordance with these findings, Mustofa et al. (2019) also agree that there is a significant correlation between selfregulated learning and their learning motivation. Same ideas derived by Xiao et al. (2019) who argued that SRL affect learning achievement.

It seems logical that seeing the result of the factors, the environment such as school and home can support learners' selfregulated learning. In school, for example, the teachers have an important role in supporting their students to be selfregulated learners (Khotimah et al., 2019) and strategies they apply should give opportunities for them to learn independently (Peel, 2020). It is surprising that teachers and parents work collaboratively to support students' SRL.

Finally, for the students who are not yet able to be self-regulated learners, the researchers suggest that they should develop the desire and learning interest individually. Supported by Silalahi, (2019) learning through listening to stories or music, watching television, reading picture books, and English magazines would be some strategies to do.

\section{CONCLUSION}

Having an excellent ability in self-regulated learning is crucial for learning achievement. Although being self-regulated learners are complicated, students can practice and learn from others. They can learn how to use strategies in learning from their peers because sharing activities will obtain good social interactions (Effeney at all, 2013). This research revealed that students' selfregulated was only at enough level, becoming self-regulated in learning is not easy to obtain. Contextually, respondents of this study have been in a good achievement, they have been trying to become selfregulated learners. Then, this enough result was influenced by four factors, they were the support of the environment; technology; the students were having high confidence; also having the desire to learn independently. In sum, the researchers believe that giving interest and much attention to those factors will develop students' ability to be self-regulated learners.

\section{REFERENCES}

Chalachew, A. A., \& Lakshmi, V. H. (2013). Factors influence students self-regulation learning towards their academic achievement in undergraduate programs in Ethiopia. Abhinav National Monthly Refereed Journal of Research in Arts \& Education, 2(7), 30-40. www.abhinavjournal.com

Cheng, C. K. E. (2011). The role of selfregulated learning in enhancing learning performance. The International Journal of Research and Review, 6(1), 1-16. https://repository.eduhk.hk/en/public ations/the-role-of-self-regulated- 
learning-in-enhancing-learningperform-7

Harding, S.-M. (2018). Self-regulated learning in the classroom As part of the Realising the Potential of Australia's High Capacity Students Linkage Project. August, 1-42.

Khotimah, K., Widiati, U., Mustofa, M., \& Faruq Ubaidillah, M. (2019). Autonomous English learning: Teachers' and students' perceptions. Indonesian Journal of Applied Linguistics, 9(2), 371-381. https://doi.org/10.17509/ijal.v9i2.202 34

Mustofa, R. F., Nabiila, A., \& Suharsono, S. (2019). Correlation of Learning Motivation with Self Regulated Learning at SMA Negeri 1 Tasikmalaya City. International Journal for Educational and Vocational Studies, 1(6), 647-650. https://doi.org/10.29103/ijevs.v1i6.17 50

National Ministry of Education Indonesia. (2003). Undang-Undang Republik Indonesia Nomor 20 Tahun 2003 tentang Sistem Pendidikan Nasional.

Ozan, C., Gundogdu, K., Bay, E., \& Celkan, H. Y. (2012). A Study on the University Students' Self-Regulated Learning Strategies Skills and SelfEfficacy Perceptions in Terms of Different Variables. Procedia Social and Behavioral Sciences, 46, 1806-1811.

https://doi.org/10.1016/j.sbspro.2012. 05.383

Panadero, E. (2017). A review of selfregulated learning: Six models and four directions for research. In Frontiers in Psychology (Vol. 8, Issue APR, p. 422). Frontiers Media S.A.

https://doi.org/10.3389/fpsyg.2017.0 0422
Peel, K. L. (2020). Everyday classroom teaching practices for self-regulated learning. Issues in Educational Research, 30(1), 260-282.

Schraw, G., Kauffman, D. F., \& Lehman, S. (2006). Self-Regulated Learning. In Encyclopedia of Cognitive Science. John Wiley \& Sons, Ltd. https://doi.org/10.1002/0470018860.s 00671

Silalahi, M. (2019). Improving Students' Interest in Learning English by Using Games. International Journal of Theory and Application in Elementary and Secondary School Education, 1(1), 50-56. https://doi.org/10.31098/ijtaese.v1i1. 24

Widoyoko, S. E. P. (2014). Teknik Penyusunan Instrumen Penelitian. Yogyakarta: Pustaka Pelajar.

Xiao, S., Yao, K., \& Wang, T. (2019). The Relationships of Self-regulated Learning and Academic Achievement in University Students. SHS Web of Conferences, 60, 01003. https://doi.org/10.1051/shsconf/2019 6001003

Zimmerman, B. J. (1990). Self-Regulated Learning and Academic Achievement: An Overview. Educational Psychologist, 25(1), 317. https://doi.org/10.1207/s15326985ep 2501_2

Zumbrunn, S., Joseph, T., \& E. Danielle, R. (2011). Encouraging SelfRegulated Learning in the Classroom_A Review of the Literature. Metropolitan Educational Research Consortium (MERC), Virginia Commonwealth University. https://doi.org/10.13140/RG.2.1.3358 .6084 